\title{
BIOMASS EQUATIONS FOR CALABRIAN PINE IN THE MEDITERRANEAN REGION OF TURKEY
}

\section{MODELI BIOMASE STABALA KALABRIJSKOG BORA U MEDITERANSKOM PODRUČJU TURSKE}

\author{
Turan SÖNMEZ* ${ }^{*}$ Aydin KAHRIMAN** ${ }^{*}$ Abdurrahman ŞAHIN**, Mehmet YAVUZ**
}

\begin{abstract}
Summary
The aim of this study was to develop allometric equations for the estimation of above-ground biomass components of Calabrian pine (Pinus brutia Ten.) tree in the Mediterranean Region of Turkey. Using regression analysis, different allometric equations were fitted for the tree components of the above-ground biomass using diameter at breast height (dbh) and tree height as estimators. Two hundred and ninety-two trees between 0.4 and $63.0 \mathrm{~cm}$ in $\mathrm{dbh}$ were randomly sampled throughout 292 natural, pure Calabrian pine stands in Turkey's Mediterranean Region, where it forms diverse stand structures. Finally, the allometric equations were developed for the tree components of the Calabrian pine tree for the stem, bark, branch, needle and total above-ground biomass. The stem, bark and total biomass equations explained more than $90 \%$ of the observed variability, while the branch and needle biomass equations explained $82 \%$ and $65 \%$, respectively.
\end{abstract}

KEY WORDS: Calabrian pine, biomass estimation, allometric equations

\section{INTRODUCTION}

\section{UVOD}

Tree biomass estimation is needed for both forest resource planning and for energy studies (Zianis et al., 2005). Estimating forest biomass can be achieved through the use of empirical allometric equations that relate several tree parameters, such as tree diameter, tree height, and crown depth (Zianis et al., 2011). Once developed, the equations can be conveniently applied to forest inventory datasets in order to obtain biomass estimates, usually for above-ground tree components at the forest stand level. These forest inventory datasets are used for biomass studies such as understanding of ecosystem material distribution, ecosystem dynamics and circulation, estimating forest carbon stock and annual carbon storage capacity, forest fire behavior, forest fire fo- recasting and determining bioenergy potential The Calabrian pine is one of the fast growing tree species in the Mediterranean area, prone to forest fire and has a big carbon storage capacity.

The carbon stocks and carbon balance are calculated based on the distribution of plant mass (as tree species and their amount of dry weight) in the forested areas. Biomass equations can be applied directly to the tree-level inventory data (e.g. diameter and height), or biomass expansion factors (BEFs) (Lehtonen et al., 2004).

Many forest biomass estimation studies have been conducted in the Mediterranean countries such as Lebonan, Syria and Turkey on above-ground biomass and include those implemented for Scots pine (Ugurlu et al., 1976), Calabrian pine (Sun et al., 1980; Durkaya et al., 2009), alder (Saraco-

\footnotetext{
* Assoc. Prof. Dr. Turan Sönmez, Ph.D., Bursa Technical University, Faculty of Forestry, 16330, Bursa, Turkey. Corresponding author: sonmez_turan@yahoo.com

**Assist. Prof. Dr. Aydin Kahriman, Assist. Prof. Dr. Abdurrahman Şahin, Assist. Prof. Dr. Mehmet Yavuz, Artvin Çoruh University, Faculty of Forestry, 08000, Artvin, Turkey
} 
glu, 1988), beech (Saracoglu, 1998) and oak (Durkaya, 1998). In fitting the biomass equations for Calabrian pine (Durkaya et al., 2009), Scots pine and alder, diameter at breast height ( $\mathrm{dbh}$ ) and tree height (h) were used as independent variables, while in the other biomass equations, only diameter at breast height was used as an explanatory variable. Furthermore, several studies have been carried out to determine the fuel loading capacities of several domestic pine species in Turkey (Kucuk et al., 2007; Kucuk and Bilgili, 2008; Kucuk et al., 2008; Mitsopoulos et al. 2016).

The aim of this study was to develop above-ground biomass equations and to estimate the whole tree biomass and the biomass of different tree components of the Calabrian pine growing in the Mediterranean Region of Turkey.

\section{MATERIALS AND METHODS}

\section{MATERIJALI I METODE}

\section{Study area - Područje istraživanja}

The study area comprised the forests of the Mediterranean Region, located in the south of Turkey (Fig. 1) (36 $06^{\circ}$ $\left.37^{\circ} 30^{\prime} \mathrm{N}, 29^{\circ} 20^{\prime}-35^{\circ} 00^{\prime} \mathrm{E}\right)$. The elevation ranges from 80 to $1114 \mathrm{~m}$ above mean sea level. The study area was covered by forest (56\%), agricultural (45\%), pasture land (23\%) and settlement (30\%) land use types. The forested lands consist of Calabrian pine (78\%), black pine (23\%), Lebonan cedar (30), oak species (12\%) and oriental beech (2\%) stands. The area has a Mediterranean climate with hot and humid summers and rainy, warm winters. The average temperature is $17.7^{\circ} \mathrm{C}$ with a min $-4.0^{\circ} \mathrm{C}$ and $\max 45.0^{\circ} \mathrm{C}$ temperature. The total annual average precipitation is $1069.8 \mathrm{~mm}$. The main geological main rock is lime stone that producing redbrown Mediterranean soils throughout the area.

\section{Data sampling - Prikupljanje podataka}

Pure Calabrian pine stands covering different site classes at different development phases were utilized in order to estimate the above-ground biomass. A total of 292 sample plots representing trees from different growing sites, stand densities, and stand ages were randomly selected. Traits of trees in each circled shape sampling plot ranging from 200 to $2000 \mathrm{~m}^{2}$ were measured. One sample tree representing average basal area within each sampling plot was cut down and the above-ground biomass was separated into stem, branches and needles. The stem was sectioned into one meter apart. A $5 \mathrm{~cm}$ wide wood disk from each section was cut for the carbon analysis. The bark thickness and dbh of each section was measured and recorded. The sections were also

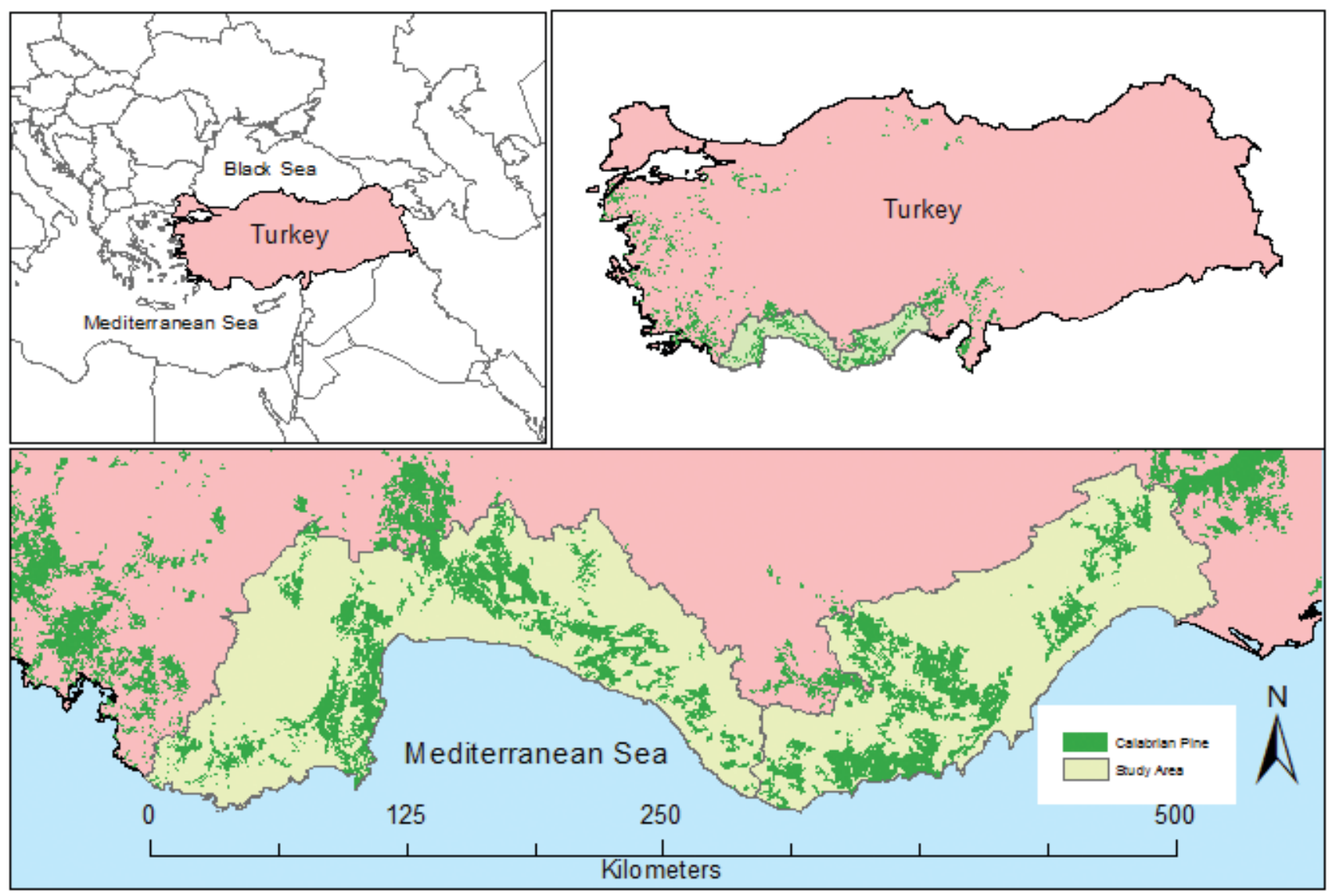

Figure 1. Location of study area Slika 1. Prikaz područja istraživanja 
weighted using a portable scale. Three live branches, one from the lowest part of the crown, one in the middle and one at the top of the crown were randomly selected. The length and dbh of each selected branches then were measured and weighted. The needles of each selected branches were removed and weighted. The 5-cm wood disks, selected branches and needles were taken to the labs and air dried for further wood density and carbon analysis. The air dried samples were then oven dried at $105^{\circ} \mathrm{C}$ for 24 hours.

The total dry biomass of the sampled tree was calculated using the following equation:

$$
D W_{i}=F W_{i} \times d w s_{i} / f w s_{i}
$$

Where;

$\mathrm{DW}_{\mathrm{i}}$ is the dry-weight of each tree component (stems, branches and needles), $\mathrm{FW}_{\mathrm{i}}$ is the total fresh weight of each component, fws $s_{i}$ is fresh weight of the sample, and $\mathrm{dws}_{\mathrm{i}}$ denotes dry weight of the sample, respectively. The $i$ represents each tree component, stems, branches and needles, respectively.

\section{Statistical analysis - Statistička analiza}

There were two kinds of equations (univariate and multivariate) for estimating the above-ground tree component biomass (Nordman et al., 2005). The univariate allometric equations are based on the diameter at breast height. On the other hand, multivariate equations use tree height, tree crown length and tree crown width in addition to dbh to estimate the above-ground tree biomass.

In practice, the measurement of dbh and tree height are much easier and less time consuming than measuring tree height, crown length, crown width, and dbh all together. Because of that the allometric equations based on $\mathrm{dbh}$ and tree height were chosen (Table 1). Using dbh and tree hei-
Table 1. Tested equations, where y is dry biomass $\left(\mathrm{kg} \mathrm{tree}^{-1}\right)$, $\mathrm{d}$ is diameter at breast height $(\mathrm{m}), \mathrm{h}$ is tree height $(\mathrm{m})$

Tablica 1. Testirane jednadžbe, pri čemu je y suha biomasa $\left(\mathrm{kg} \mathrm{stabla}^{-1}\right), \mathrm{d}$ je prsni promjer (m), h je visina stabla (m)

\begin{tabular}{cll}
$\begin{array}{c}\text { Equation number } \\
\text { Broj jednadžbe }\end{array}$ & Expression \\
\hline 1 & $\ln y=b_{0}+b_{1} \ln d$ \\
2 & $\ln y=b_{0}+b_{1} \ln d+b_{2} \ln h$ \\
3 & $\ln y=b_{0}+b_{1} \ln d+b_{2} h+b_{3} \ln h$ \\
4 & $\ln y=b_{0}+b_{1} d+b_{2} \ln d+b_{3} h$ \\
5 & $\ln y=b_{0}+b_{1} \ln \left(d^{2} h\right)$ \\
6 & $\ln y=b_{0}+b_{1} \ln d+b_{2} \ln \left(d^{2} h\right)$ \\
7 & $\ln y=b_{0}+b_{1} \ln d+b_{2} \ln d^{2}+b_{3} \ln h$ \\
8 & $\ln y=b_{0}+b_{1} \ln d+b_{2} \ln h+b_{3} d / h^{2}$ \\
9 & $\ln y=b_{0}+b_{1} d /\left(d+b_{2}\right)$ \\
10 & $\ln y=b_{0}+b_{1} d /\left(d+b_{2}\right)+b_{3} h$ \\
11 & $\ln y=b_{0}+b_{1} d /\left(d+b_{2}\right)+b_{3} \ln h$ \\
12 & $\ln y=b_{0}+b_{1} d /\left(d+b_{2}\right)+b_{3} h+b_{4} \ln h$
\end{tabular}

ght, 12 different allometric equations (Table 1) were tested for the prediction of the above-ground biomass of Calabrian pine. These allometric equations were used for the stem, branches and needles separately. The allometric equations presented in this study then were fitted using linear and nonlinear regression analysis.

\section{Model Evaluation - Evaluacija modela}

To select the best models for each tree components of the above-ground biomass, the following criteria were utilized using SPSS statistical software package: a) coefficient of determination $\left(\mathrm{R}^{2}\right), \mathrm{b}$ ) residual standard error (RSE), and $c$ ) $p$ values of estimated parameters. The selected models were sorted in descending order based on $\mathrm{R}^{2}$ and given a highest rank score for the highest R2 model. The models were sor-

Table 2. Descriptive statistics of the 292 sampled trees.

Tablica 2. Deskriptivna statistika za 292 uzorkovana stabala.

\begin{tabular}{|c|c|c|c|c|}
\hline $\begin{array}{l}\text { Variables } \\
\text { Varijable }\end{array}$ & $\begin{array}{l}\text { Minimum } \\
\text { Minimum }\end{array}$ & $\begin{array}{l}\text { Maximum } \\
\text { Maksimum }\end{array}$ & $\begin{array}{c}\text { A. Mean } \\
\text { Srednja vrijednost }\end{array}$ & $\begin{array}{c}\text { Std. Deviation } \\
\text { Standardna devijacija }\end{array}$ \\
\hline $\begin{array}{l}\text { Diameter at breast height }(\mathrm{cm}) \\
\text { Prsni promjer }(\mathrm{cm})\end{array}$ & 0.40 & 63.0 & 24.6 & 13,0 \\
\hline $\begin{array}{l}\text { Tree height }(\mathrm{m}) \\
\text { Visina stabla }(\mathrm{m})\end{array}$ & 1.50 & 28.1 & 13.9 & 6,6 \\
\hline $\begin{array}{l}\text { Dry matter in branches }(\mathrm{kg} \text { tree } \\
\text { Suha tvar u granama }(\mathrm{kg} \text { stabla }\end{array}$ & 0.01 & 444.8 & 49.1 & 70,0 \\
\hline $\begin{array}{l}\text { Dry matter in needles }\left(\mathrm{kg} \mathrm{tree}^{-1}\right) \\
\text { Suha tvar u iglicama }\left(\mathrm{kg} \mathrm{stabla}^{-1}\right)\end{array}$ & 0.08 & 197.8 & 13.4 & 21,1 \\
\hline $\begin{array}{l}\text { Dry matter in stem }\left(\mathrm{kg} \mathrm{tree}^{-1}\right) \\
\text { Suha tvar u deblu }\left(\mathrm{kg} \text { stabla }^{-1}\right)\end{array}$ & 0.01 & 923.9 & 180.3 & 188,2 \\
\hline $\begin{array}{l}\left.\text { Dry matter in bark (kg tree }{ }^{-1}\right) \\
\text { Suha tvar u kori }\left(\mathrm{kg} \mathrm{stabla}^{-1}\right)\end{array}$ & 0.01 & 332.5 & 41.5 & 50,0 \\
\hline $\begin{array}{l}\text { Total dry matter }\left(\mathrm{kg} \mathrm{tree}^{-1}\right) \\
\text { Ukupna suha tvar }\left(\mathrm{kg} \mathrm{stabla}^{-1}\right)\end{array}$ & 0.46 & 1417.0 & 284.3 & 291,5 \\
\hline
\end{tabular}



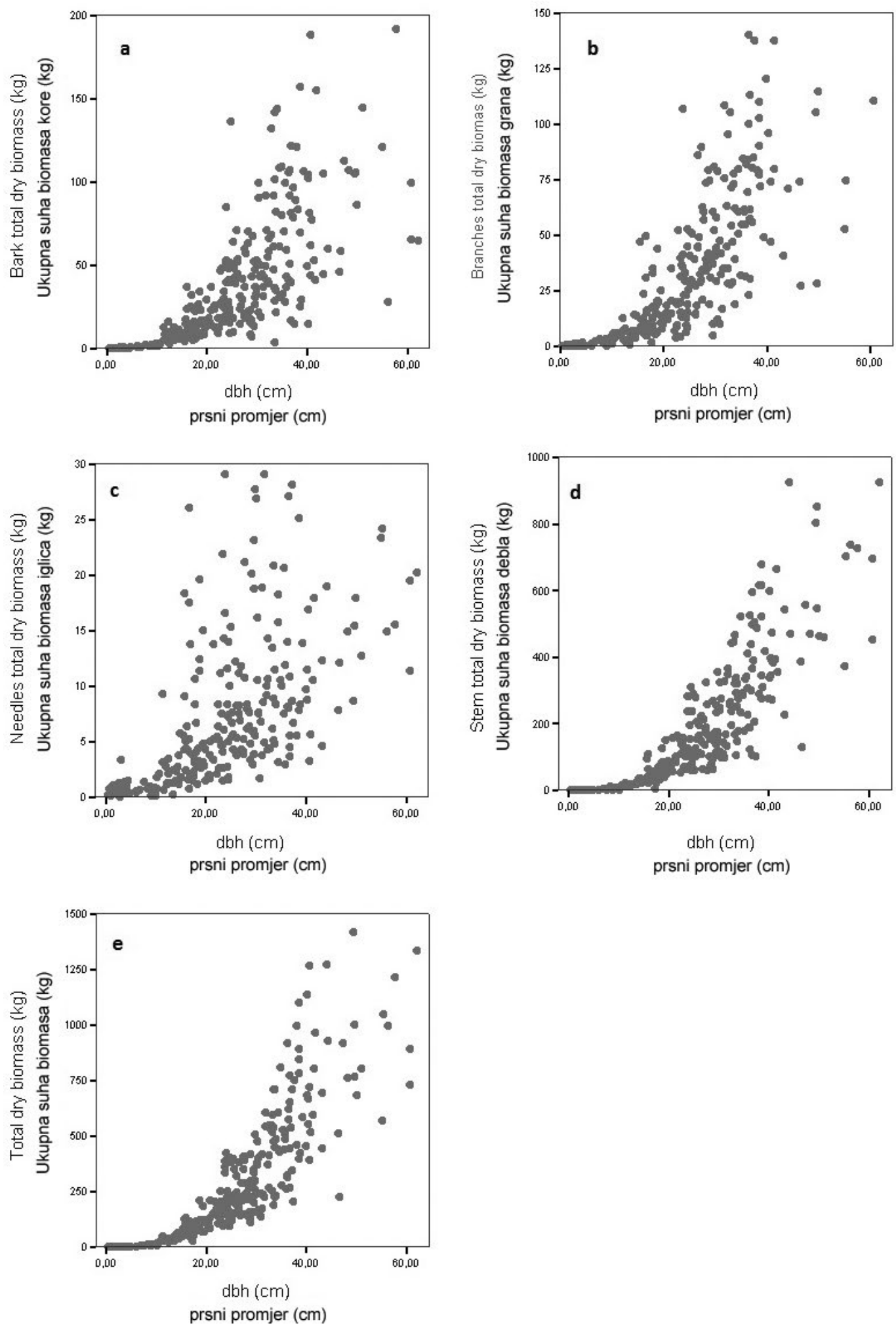

Figure 2. Observed biomass values of the tree components: (a) branch, (b) bark, (c) needle, (d) stem and (e) total dry biomass. Slika 2. Utvrđeni (izmjereni) iznosi biomase suhe tvari prema sastavnicama stabla: (a) grane, (b) kora, (c) iglice, (d) deblo i (e) ukupno.

ted in ascending order based on RSE and the highest score was given to the lowest RSE model. Any models that had a p-value greater than 0.05 or any models' p-value of estimated parameters that was greater than 0.05 were eliminated.
The $\mathrm{R}^{2}$ and RSE rank scores were summed and the model that had the highest total score was selected as the best fit allometric equation for estimating above-ground biomass for each tree component. 
Table 3. Some analysis of all tested models for each component

Tablica 3. Neke analize svih testiranih modela za svaku pojedinu komponentu

\begin{tabular}{|c|c|c|c|c|c|c|c|c|c|c|}
\hline \multirow{2}{*}{ 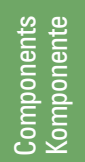 } & \multirow{2}{*}{ 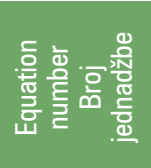 } & \multicolumn{4}{|c|}{ Equation criteria - Kriteriji jednadžbe } & \multicolumn{5}{|c|}{$\begin{array}{c}\text { Parameter criteria - Parametar kriterija } \\
\qquad p \text { values of }-p \text { vrijednosti }\end{array}$} \\
\hline & & $\mathrm{R}^{2}$ & PSP & p vrijednosti & Rang & $\mathrm{b}_{0}$ & $b_{1}$ & $b_{2}$ & $b_{3}$ & $b_{4}$ \\
\hline \multirow{12}{*}{ 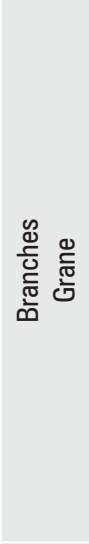 } & 4 & 0,84 & 0,75 & 0,000 & & 0,000 & 0,000 & 0,000 & 0,222 & \\
\hline & 8 & 0,82 & 0,78 & 0,000 & & 0,013 & 0,000 & 0,828 & 0,001 & \\
\hline & 3 & 0,82 & 0,79 & 0,000 & & 0,000 & 0,000 & 0,031 & 0,384 & \\
\hline & 6 & 0,82 & 0,80 & 0,000 & & 0,000 & 0,118 & 0,000 & & \\
\hline & 7 & 0,82 & 0,80 & 0,000 & & 0,000 & 0,224 & 0,000 & 0,000 & \\
\hline & 2 & 0,82 & 0,80 & 0,000 & 14 & 0,000 & 0,000 & 0,000 & & \\
\hline & 5 & 0,82 & 0,80 & 0,000 & 12 & 0,000 & 0,000 & & & \\
\hline & 1 & 0,80 & 0,83 & 0,000 & 10 & 0,000 & 0,000 & & & \\
\hline & 12 & 0,79 & 0,86 & 0,000 & 8 & 0,000 & 0,000 & 0,000 & 0,000 & 0,000 \\
\hline & 11 & 0,78 & 0,87 & 0,000 & 6 & 0,000 & 0,000 & 0,000 & 0,000 & \\
\hline & 10 & 0,71 & 1,01 & 0,000 & 4 & 0,000 & 0,000 & 0,000 & 0,000 & \\
\hline & 9 & 0,71 & 1,10 & 0,000 & 2 & 0,000 & 0,000 & 0,000 & & \\
\hline \multirow{12}{*}{$\begin{array}{l}\mathscr{d} \\
\frac{\mathscr{J}}{\bar{d}} \\
\frac{\Phi}{2}\end{array}$} & 10 & 0,65 & 0,73 & 0,000 & 14 & 0,000 & 0,000 & 0,000 & 0,000 & \\
\hline & 9 & 0,65 & 0,74 & 0,000 & 12 & 0,000 & 0,000 & 0,000 & & \\
\hline & 4 & 0,62 & 0,76 & 0,000 & & 0,000 & 0,001 & 0,000 & 0,778 & \\
\hline & 8 & 0,61 & 0,77 & 0,000 & & 0,194 & 0,000 & 0,763 & 0,043 & \\
\hline & 3 & 0,61 & 0,78 & 0,000 & & 0,000 & 0,000 & 0,259 & 0,573 & \\
\hline & 5 & 0,60 & 0,78 & 0,000 & 9 & 0,000 & 0,000 & & & \\
\hline & 2 & 0,60 & 0,78 & 0,000 & 9 & 0,000 & 0,000 & 0,008 & & \\
\hline & 7 & 0,60 & 0,78 & 0,000 & & 0,000 & & 0,000 & 0,008 & \\
\hline & 6 & 0,60 & 0,78 & 0,000 & & 0,000 & 0,370 & 0,008 & & \\
\hline & 1 & 0,59 & 0,79 & 0,000 & 6 & 0,000 & 0,000 & & & \\
\hline & 12 & 0,58 & 0,80 & 0,000 & 4 & 0,000 & 0,000 & 0,000 & 0,000 & 0,000 \\
\hline & 11 & 0,58 & 0,80 & 0,000 & 2 & 0,000 & 0,000 & 0,000 & 0,000 & \\
\hline \multirow{12}{*}{ 产 } & 8 & 0,90 & 0,63 & 0,000 & & 0,000 & 0,000 & 0,211 & 0,032 & \\
\hline & 6 & 0,90 & 0,64 & 0,000 & & 0,000 & 0,300 & 0,000 & & \\
\hline & 7 & 0,90 & 0,64 & 0,000 & & 0,000 & & 0,000 & 0,000 & \\
\hline & 2 & 0,90 & 0,64 & 0,000 & 14 & 0,000 & 0,000 & 0,000 & & \\
\hline & 5 & 0,90 & 0,64 & 0,000 & 12 & 0,000 & 0,000 & & & \\
\hline & 3 & 0,90 & 0,64 & 0,000 & & 0,000 & 0,000 & 0,797 & 0,001 & \\
\hline & 4 & 0,89 & 0,65 & 0,000 & & 0,000 & 0,881 & 0,000 & 0,000 & \\
\hline & 1 & 0,88 & 0,67 & 0,000 & 10 & 0,000 & 0,000 & & & \\
\hline & 12 & 0,86 & 0,73 & 0,000 & 8 & 0,000 & 0,000 & 0,000 & 0,000 & 0,000 \\
\hline & 11 & 0,86 & 0,74 & 0,000 & 6 & 0,000 & 0,000 & 0,000 & 0,000 & \\
\hline & 10 & 0,79 & 0,90 & 0,000 & 4 & 0,000 & 0,000 & 0,000 & 0,000 & \\
\hline & 9 & 0,51 & 1,38 & 0,000 & 2 & 0,000 & 0,000 & 0,000 & & \\
\hline \multirow{12}{*}{ 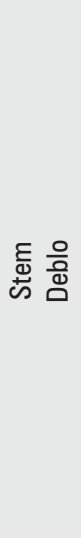 } & 10 & 0,95 & 0,50 & 0,000 & 18 & 0,000 & 0,000 & 0,000 & 0,000 & \\
\hline & 8 & 0,94 & 0,54 & 0,000 & 16 & 0,000 & 0,000 & 0,000 & 0,024 & \\
\hline & 6 & 0,94 & 0,54 & 0,000 & 14 & 0,000 & 0,000 & 0,000 & & \\
\hline & 7 & 0,94 & 0,54 & 0,000 & & 0,000 & & 0,000 & 0,000 & \\
\hline & 2 & 0,94 & 0,54 & 0,000 & 12 & 0,000 & 0,000 & 0,000 & & \\
\hline & 3 & 0,94 & 0,54 & 0,000 & & 0,000 & 0,000 & 0,840 & 0,000 & \\
\hline & 9 & 0,94 & 0,54 & 0,000 & 10 & 0,000 & 0,000 & 0,000 & & \\
\hline & 5 & 0,93 & 0,58 & 0,000 & 8 & 0,000 & 0,000 & & & \\
\hline & 4 & 0,93 & 0,58 & 0,000 & & 0,000 & 0,283 & 0,000 & 0,000 & \\
\hline & 12 & 0,93 & 0,62 & 0,000 & 6 & 0,000 & 0,000 & 0,000 & 0,000 & 0,000 \\
\hline & 11 & 0,92 & 0,63 & 0,000 & 4 & 0,000 & 0,000 & 0,000 & 0,000 & \\
\hline & 1 & 0,91 & 0,68 & 0,000 & 2 & 0,000 & 0,000 & & & \\
\hline
\end{tabular}




\begin{tabular}{|c|c|c|c|c|c|c|c|c|c|c|}
\hline \multirow{12}{*}{ 焉高 } & 10 & 0,96 & 0,36 & 0,000 & 22 & 0,000 & 0,000 & 0,000 & 0,000 & \\
\hline & 9 & 0,96 & 0,40 & 0,000 & 20 & 0,000 & 0,000 & 0,000 & & \\
\hline & 3 & 0,94 & 0,45 & 0,000 & 18 & 0,000 & 0,000 & 0,000 & 0,000 & \\
\hline & 8 & 0,94 & 0,45 & 0,000 & 16 & 0,009 & 0,000 & 0,000 & 0,020 & \\
\hline & 4 & 0,94 & 0,46 & 0,000 & 14 & 0,000 & 0,003 & 0,000 & 0,000 & \\
\hline & 6 & 0,94 & 0,46 & 0,000 & 12 & 0,000 & 0,000 & 0,000 & & \\
\hline & 7 & 0,94 & 0,46 & 0,000 & 0 & 0,000 & & 0,000 & 0,000 & \\
\hline & 2 & 0,94 & 0,46 & 0,000 & 10 & 0,000 & 0,000 & 0,000 & & \multirow{5}{*}{0,000} \\
\hline & 5 & 0,93 & 0,49 & 0,000 & 8 & 0,000 & 0,000 & & & \\
\hline & 12 & 0,93 & 0,49 & 0,000 & 6 & 0,000 & 0,000 & 0,000 & 0,000 & \\
\hline & 11 & 0,93 & 0,50 & 0,000 & 4 & 0,000 & 0,000 & 0,000 & 0,000 & \\
\hline & 1 & 0,91 & 0,57 & 0,000 & 2 & 0,000 & 0,000 & & & \\
\hline
\end{tabular}

\section{RESULTS AND DISCUSSION REZULTATI I RASPRAVA}

The descriptive statistics of 292 sample trees' traits were depicted in Table 2. The average dbh and tree height for the study area were $24.6 \mathrm{~cm}$ and $13.9 \mathrm{~m}$, respectively. The observed values of the above-ground biomass for the tree components were plotted against the dbh in Figure 2. It can be observed that the above-ground biomass values strongly follow an exponential relationship between $\mathrm{dbh}$ and tree height for all components.
Using dbh and tree height, the 12 different allometric equations were tested and the results were shown in Table 3 for the tree components above-ground biomass. The results of regression analysis showed that both estimators used in the selected models were statistically significant $(\mathrm{p}<0.05)$ ( Table 3). However, the coefficients of parameters of the model numbers 3, 4, 6, 7 and 8 for branches, the model numbers $3,4,6,7$ and 8 for barks, the model numbers 3,4 and 7 for stems and the model numbers $3,4,6,7$ and 8 for needles were not significant estimators $(p>0.05)$. Therefore, the above models were eliminated and excluded from the final model evaluation.

Table 4. Selected biomass equations and fitting statistics for tree components

Tablica 4. Odabrane jednadžbe biomase i statistički parametri modeliranja za pojedine sastavnice stabla

\begin{tabular}{|c|c|c|c|c|c|}
\hline $\begin{array}{l}\text { Equation } \\
\text { Jednadžba }\end{array}$ & $\begin{array}{l}\text { Components } \\
\text { Komponente }\end{array}$ & $\begin{array}{l}\text { Par. } \\
\text { Par. }\end{array}$ & $\begin{array}{c}\text { Est. } \\
\text { Procjena }\end{array}$ & $\begin{array}{l}\text { Std. error } \\
\text { Std. greška }\end{array}$ & $\begin{array}{c}p \text { values } \\
p \text { vrijednosti }\end{array}$ \\
\hline \multirow{3}{*}{$\ln y=b_{0}+b_{1} \ln d+b_{2} \ln h$} & \multirow{3}{*}{$\begin{array}{l}\text { Branches } \\
\text { Grane }\end{array}$} & $\mathrm{b}_{0}$ & -2.611 & 0.170 & 0,000 \\
\hline & & $b_{1}$ & 1.069 & 0.144 & 0,000 \\
\hline & & $\mathrm{b}_{2}$ & 0.950 & 0.196 & 0,000 \\
\hline \multirow{3}{*}{$\ln y=b_{0}+b_{1} \ln d+b_{2} \ln h$} & \multirow{3}{*}{$\begin{array}{l}\text { Bark } \\
\text { Kora }\end{array}$} & $\mathrm{b}_{0}$ & -3.254 & 0.136 & 0,000 \\
\hline & & $b_{1}$ & 1.314 & 0.116 & 0,000 \\
\hline & & $b_{2}$ & 0.878 & 0.157 & 0,000 \\
\hline \multirow{2}{*}{$+b_{3} h$} & \multirow{4}{*}{$\begin{array}{l}\text { Stem } \\
\text { Deblo }\end{array}$} & $b_{0}$ & -3.107 & 0.168 & 0,000 \\
\hline \multirow{2}{*}{$\ln y=b_{0}+b_{1}$} & & $b_{1}$ & 9.480 & 0.340 & 0,000 \\
\hline & & $\mathrm{b}_{2}$ & 9.499 & 0.909 & 0,000 \\
\hline & & $\mathrm{b}_{3}$ & 0.070 & 0.010 & 0,000 \\
\hline \multirow{4}{*}{$+b_{3} h$} & \multirow{4}{*}{$\begin{array}{l}\text { Needles } \\
\text { Iglice }\end{array}$} & $\mathrm{b}_{0}$ & -1.152 & 6.122 & 0,000 \\
\hline & & $\mathrm{b}_{1}$ & 6.483 & 0.016 & 0,000 \\
\hline & & $\mathrm{b}_{2}$ & 25.940 & 0.180 & 0,000 \\
\hline & & $\mathrm{b}_{3}$ & -0.017 & 0.890 & 0,000 \\
\hline \multirow{4}{*}{$\ln y=b_{0}+b_{1}$} & \multirow{4}{*}{$\begin{array}{l}\text { Total } \\
\text { Ukupno }\end{array}$} & $\mathrm{b}_{0}$ & -0.770 & 1.111 & 0,000 \\
\hline & & $b_{1}$ & 7.829 & 0.008 & 0,000 \\
\hline & & $\mathrm{b}_{2}$ & 12.843 & 0.109 & 0,000 \\
\hline & & $b_{3}$ & 0.056 & 0.311 & 0,000 \\
\hline
\end{tabular}



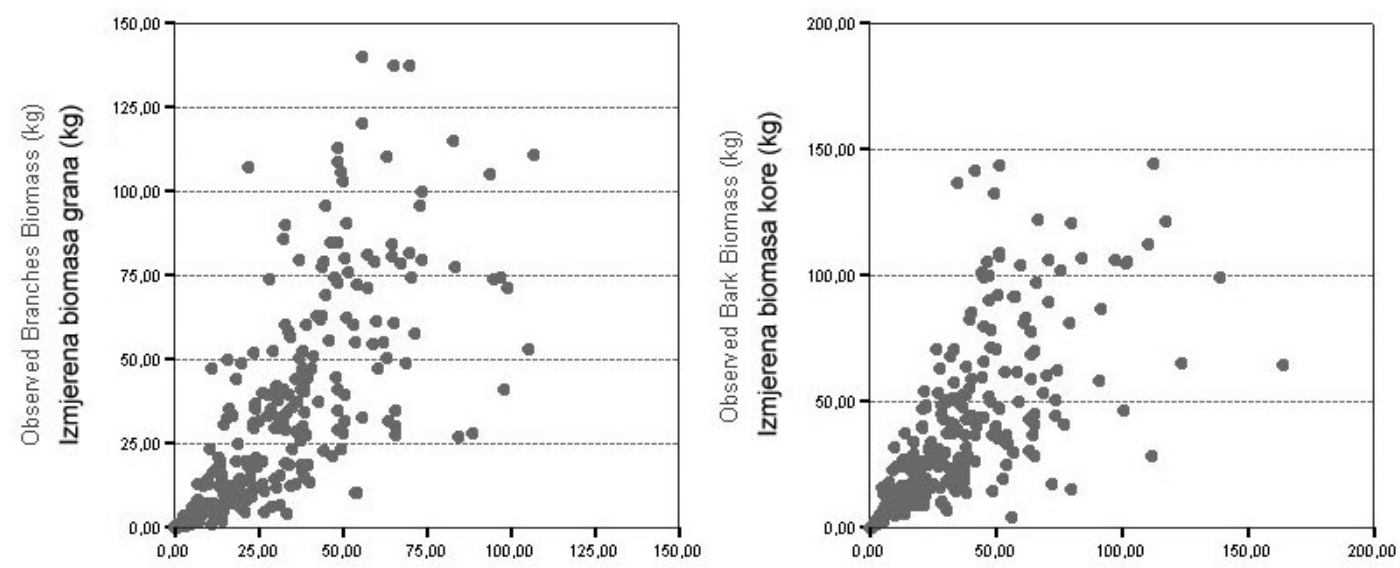

Predicted Branches Biomass $(\mathrm{kg})$

Modelirana biomasa grana $(\mathrm{kg})$

Predicted Bark Biomass ( $\mathrm{kq})$

Modelirana biomasa kore $(\mathrm{kg})$

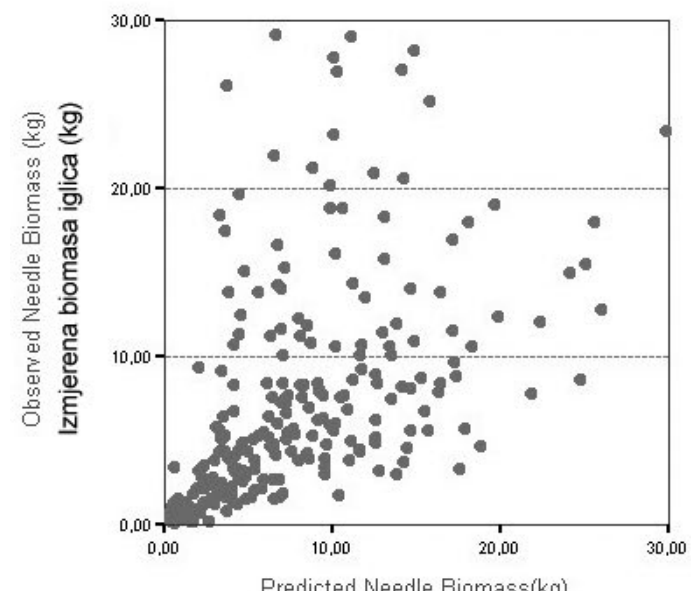

Predicted Needle Biomass $(\mathrm{kg})$

Modelirana biomasa iglica $(\mathrm{kg})$

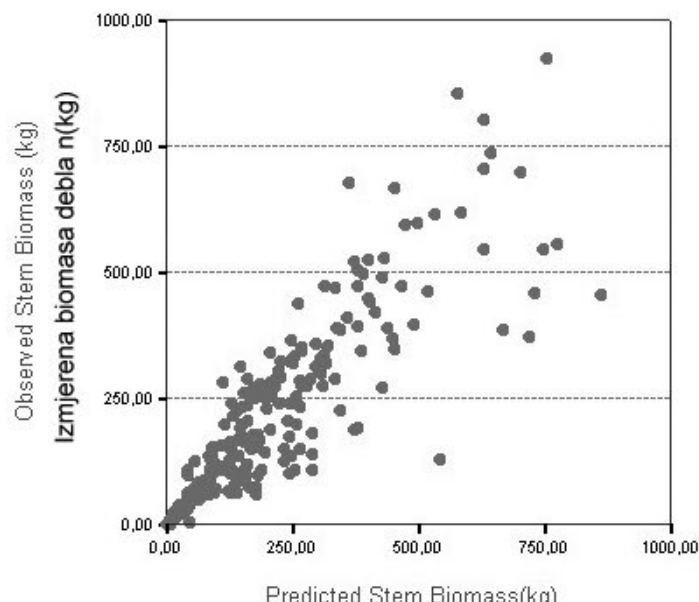

Modelirana biomasa debla $(\mathrm{kg}$

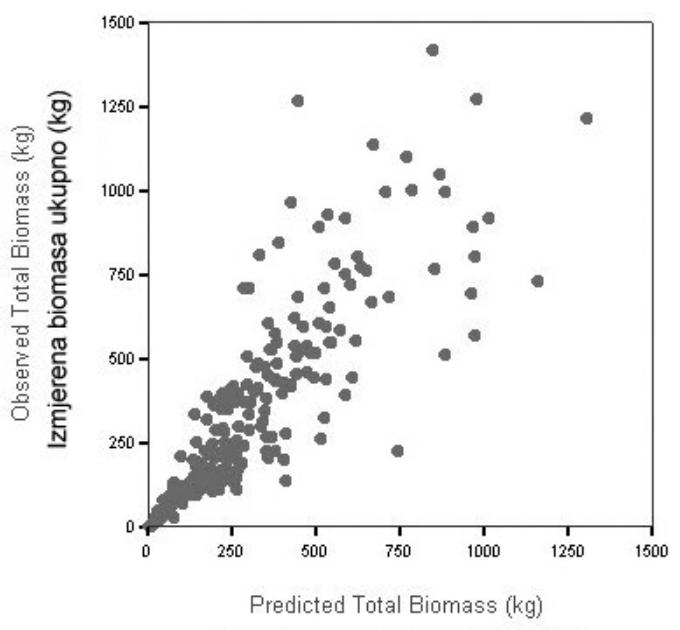

Modelirana biomasa ukupno $(\mathrm{kg})$

Fig 3. Observer vs. predicted above ground biomass by tree components

Slika 3. Izmjerene u odnosu na modelirane iznose nadzemne biomase prema sastavnicama stabla

\section{RESULTS OF MODEL EVALUATION}

\section{REZULTATI VREDNOVANJA}

The results of the regression analysis of the 12 allometric equations (Table 3) showed that the model number 2 was the best fit $\left(\mathrm{R}^{2}=0.82, \mathrm{RSE}=0.80\right)$ and the model number 9 was the least fit model for the branch biomass estimation $\left(\mathrm{R}^{2}=0.71, \mathrm{RSE}=1.10\right)$. For estimating needle biomass, the model number 10 was the strongest fit $\left(\mathrm{R}^{2}=0.65, \mathrm{RSE}=0.73\right)$ and the model number 11 was the weakest fit $\left(\mathrm{R}^{2}=0.58\right.$, 
RSE $=0.80)$. The best model for estimating bark biomass was model number $2\left(\mathrm{R}^{2}=0.90, \mathrm{RSE}=0.64\right)$ and model number 9 for the least fit $\left(\mathrm{R}^{2}=0.51, \mathrm{RSE}=1.38\right)$. The best allometric equation for stem biomass estimation was model number $10\left(R^{2}=0.95, R S E=0.50\right)$ and the least one was model number $1\left(\mathrm{R}^{2}=0.91, \mathrm{RSE}=0.68\right)$. The model number 10 $\left(\mathrm{R}^{2}=0.96, \mathrm{RSE}=0.36\right)$ was the best fit model and the model number $1\left(R^{2}=0.91, R S E=0.57\right)$ was the least fit model for estimating the total above-ground biomass of Calabrian pine tree. Table 4 depicts the fitting statistics of the selected allometric equations for estimating above-ground biomass of each tree components.

One of the advantages of the fitted allocation equations was to provide accurate estimation of above-ground tree biomass if an adequate statistical sampling design and large number of sample size ( $>100$ trees) were taken as reported by Chave et al. (2004) and Miguel et al. (2014). Many researches (Sun et al. (1980), Bilgili and Kucuk (2009), Durkaya et al. (2009), and Zianis et al. (2011)) estimating the Calabrian pine tree' above-ground biomass were taken small number of samples $(14,35,33$, and 12, respectively). Miguel et al. (2014) took 201 sample trees, whereas in this study, a total of 292 trees were randomly selected for precise estimating of above-ground biomass of tree components.

The size distribution of this study (ranged from $0.40 \mathrm{~cm}$ to $62.0 \mathrm{~cm}$ ) was wider than any other studies in the region (Miguel et al. 2014: 2.3-55.8 cm; Sun et al. 1980: 9.0-39.8 cm; Bilgili and Kucuk 2009: 13.0-19.0). The dbh and large sample variability of sample trees in size increase fitting between observed and predicted values and provide unbiased biomass estimates for the smaller trees (Navar 2009).
Table 5. $R^{2}$ and RSE values between this study and previous studies Table 5. Vrijednosti $\mathrm{R}^{2}$ i RSE između ovog istraživanja i prethodnih istraživanja

\begin{tabular}{|c|c|c|c|c|}
\hline $\begin{array}{l}\text { Components } \\
\text { Komponente }\end{array}$ & $\begin{array}{l}\text { 六 } \\
\text { 岕 } \\
\text { 号 } \\
\text { F }\end{array}$ & 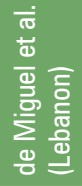 & 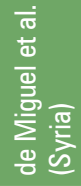 & 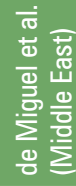 \\
\hline \multirow{2}{*}{ Branches - Grane } & $\mathrm{R}^{2}$ & 0,82 & 0,824 & 0,916 \\
\hline & RSE & 0,795 & 0,811 & 0,455 \\
\hline \multirow{2}{*}{ Bark - Kora } & $\mathrm{R}^{2}$ & 0,9 & & \\
\hline & RSE & 0,637 & & \\
\hline \multirow{2}{*}{ Stem - Deblo } & R2 & 0,95 & 0,917 & 92 \\
\hline & RSE & 0,503 & 0,185 & 0,153 \\
\hline \multirow{2}{*}{ Needles - Iglice } & $\mathrm{R}^{2}$ & 0,65 & 0,952 & 0,945 \\
\hline & RSE & 0,735 & 0,442 & 0,369 \\
\hline \multirow{2}{*}{$\begin{array}{l}\text { Total Biomass } \\
\text { Ukupna biomasa }\end{array}$} & $\mathrm{R}^{2}$ & 0,96 & 0,737 & 0,893 \\
\hline & RSE & 0,363 & 0,681 & 0,225 \\
\hline
\end{tabular}

However, inclusion of trees that less than $8.0 \mathrm{~cm}$ in this study helps unbiased prediction of fire behavior about forest fuels in the fire-prone Calabrian pine stands (Bilgili and Kucuk 2009; Matropolous et al. 2016).

The correlation between biomass and dbh and/or tree height were found strong as expected and reported on the other studies (Ketterings et al. 2001). However, inclusion of the tree height as the second estimator decreased residual variation by $\% 4$ for branches, $\% 0.2$ for needles, $\% 5$ for barks, $\% 8$ for stems, and $\% 8$ for total tree biomass, respectively.

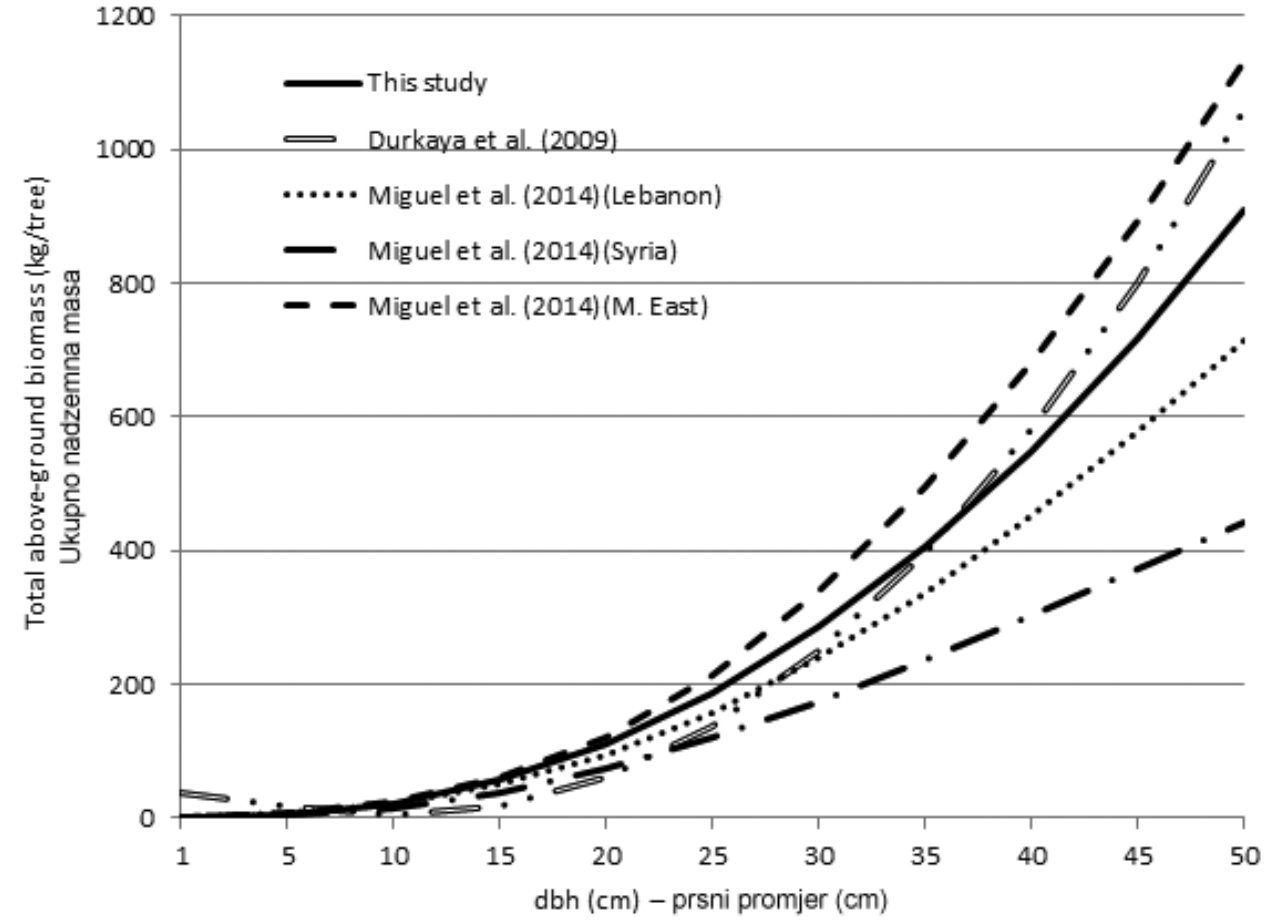

Figure 4. Previously published equations for Calabrian pine compared with those of this study. Slika 4. Prethodno objavljene jednadžbe za kalabrijski bor u usporedbi s onima iz ove studije. 
Therefore, caution should be given when using the dbh as a single estimator in the above-ground biomass equations (Chave et al. 2005).

We found the similar fluctuations between the independent variables for the needle biomass estimation with other studies (Grigal and Kernik, 1984; Miksys et al., 2007). On the other hand, the correlations between observed and predicted values of branches and needle biomass were relatively low. These differences were attributed to the nonstandard treatments of each forest stand throughout the entire study area.

The coefficient of determination and residual standard error values of this study and de Miguel et al. (2014) were depicted in Table 5 for model performance comparison. Our models were estimated the stem and total tree biomass better than that of de Miguel et al. (2014) models. On the other hand, de Miguel et al. (2014) models were better estimating branch and needle biomass than that of our models. It can be observed that the improved equations for Syria and Lebanon by de-Miguel et al. (2014) gave the two lowest estimations of the above ground biomass. The model developed in this study estimated lower biomass values than the equations improved by de-Miguel et al. (2014) for the Middle East.

As depicted in Figure 4, the total tree biomass estimation using dbh and tree height as double-entry estimators varied amongst the researchers studying the Calabrian pine tree growth in the Mediterranean region. Durkaya (2009) and de Miguel et al. (2014) for Syria and Lebanon were underestimated the total tree biomass comparing the estimation results from this study for dbh values less than $35 \mathrm{~cm}$. Thus, de Miguel et al. (2014)'s model for estimating total tree biomass in the MiddleEast was better than any other models for the less than $35 \mathrm{~cm}$ dbh range. The diameter at breast height values that were more than $35 \mathrm{~cm}$ were overestimated by de Miguel et al. (2014) for the MiddleEast and Durkaya (2009) and were underestimated for Syria and Lebanon from our models. However, our above-ground biomass estimations were accurate and nonbiased.

\section{CONCLUSION}

\section{RASPRAVA}

We have shown that above-ground biomass equations for Calabrian pine trees could be used for estimating individual tree component biomasses. A system of five biomass equations (stem, bark, branch, needle and total biomass) was developed. The stem, bark and total biomass equations explained more than $90 \%$ of the variability of the observed data, while the branch and needle biomass equations accounted for $82 \%$ and $65 \%$, respectively. In this study, bark and stem biomass were separately estimated so that their contribution to the total tree biomass could be explained more accurately. We can conclude that our above-ground and tree components biomass estimations were accurate and nonbiased. For more accurate estimation of branch and needle biomass, it would be advisable to add other tree parameters such as crown length and/or crown diameter to fit the data.

\section{ACKNOWLEDGMENTS}

\section{ZAHVALE}

This study was carried out as part of a project financed by the Scientific and Technological Research Council of Turkey (TUBİTAK) (Project No. TOVAG-112O808). The authors wish to thank the other researchers and workers who contributed to this project. The authors declare that they have no conflict of interest.

\section{REFERENCES}

\section{LITERATURA}

- Bilgili, E., O. Kucuk. 2009: Estimating above-ground fuel biomass in young Calabrian pine (Pinus brutia Ten.). Energy Fuel 23:1797-1800.

- Chave, J., R. Condit, S. Aguilar, A. Hernandez, S. Lao, R. Perez, 2004: Error propagation and scaling for tropical forest biomass estimates. Phil. Trans. R. Soc. Lond. B. 359:409-420.

- de-Miguel, S., T. Pukkala, N. Assaf, Z. Shater, 2014: Intra-specific differences in allometric equations for aboveground biomass of eastern Mediterranean Pinus brutia. Annals of Forest Science. 71:101-112.

- Durkaya, B., 1998: Construction of biomass tables of oak stands in Zonguldak forest enterprise. Dissertation (M.Sc. thesis), Zonguldak, 110 p. (in Turkish).

- Durkaya, A., B. Durkaya, A. Ünsal, 2009: Predicting the aboveground biomass of calabrian pine (Pinus brutia Ten.) stands in Turkey. Afr J Biotechnol. 8:2483-2488.

- Grigal, D.F., L.K. Kernik, 1984: Generality of black spruce biomass estimation equations. Can. J. For. Res. 14(3): 468-470.

- Ketterings, Q.M., R. Coe, M. van Noordwijk, C.A. Palm, 2001: Reducing uncertainty in the use of allometric biomass equations for predicting above-ground tree biomass in mixed secondary forests. Forest Ecology and management, 146(1), 199-209.

- Kucuk, O., B. Saglam, E. Bilgili, 2007: Canopy fuel characteristics and fuel load in young Black pine trees. Biotechnology \& Biotechnological Equipment. 21(2): 235-240.

- Kucuk, O., E. Bilgili, 2008: Crown fuel characteristics and fuel load estimates in young Calabrian pine (Pinus brutia Ten.) stands in Northwestern Turkey. Fresenius Environ. Bull. 17: 2226-2231.

- Kucuk, O., E. Bilgili, B. Saglam, 2008: Estimating crown fuel loading for Calabrian pine and Anatolian black pine. Int. J. Wildland Fire. 17: 147-154.

- Lehtonen, A., R. Mäkipää, J. Heikkinen, R. Sievänen, J. Liski, 2004: Biomass expansion factors (BEF) for Scots pine, Norway spruce and birch according to stand age for boreal forests. For. Ecol. Manage. 188: 211-224.

- Miksys, V., I. Varnagiryte-Kabasinskiene, I. Stupak, K. Armolaitis, M. Kukkola, J. Wojcik, 2007: Above-ground biomass functions for scots pine in Lithuania. Biom. Bioe. 31: 685-692. 
- Mitsopoulos, I., G. Mallinis, S. Zibtsev, M. Yavuz, B. Saglam, O. Kucuk, V. Bogomolov, A. Borsuk, G. Zaimes. 2016: An integrated approach for mapping fire suppression difficulty in three different ecosystems of Eastern Europe. Journal of Spatial Science, 1-17.

- Nordman E. E., D. J. Robison, L. P. Abrahamson, T. A. Volk, 2005: Relative resistance of willow and poplar biomass production clones across a continuum of herbivorous insect specialization: Univariate and multivariate approaches. For. Ecol. Manage. 217: 307-318.

- Phillip, M., 1994: Measuring trees and forests. UK and USA: CABI Publishing, $310 \mathrm{p}$.

- Saracoglu, N., 1988: Construction stem volume and biomass tables of black alder. Dissertation (Ph.D. thesis). Faculty of Forestry, Trabzon, 152 p. (in Turkish).
- Saracoglu, N., 1998: Beech (Fagus orientalis Lipsky) biomass tables. Turk. J. Agric. For. 22: 93-100.

- Sun, O., S, Ugurlu. E. Ozer, 1980: Determination of biomass of Calabrian pine stands. Forestry Research Institute Publications, 32 p., Ankara, (in Turkish).

- Ugurlu, S., O. Sun, B. Arasl1, 1976: Determination of biomass of Scots pine stands. Technical Bulletin No 80. Ankara (Turkey): Forestry Research Institute Publications, 48 p., Ankara, (in Turkish)

- Zianis, D., P. Muukkonen, R. Mäkipää, M. Mencuccini, 2005: Biomass and stem volume equations for tree species in Europe, Silva Fenn Monographs 4, 63 p., Tampere, Finland.

- Zianis, D., G. Xanthopoulos, K. Kalabodikis, G. Kazakis, D. Ghosn, O. Roussou, 2011: Allometric equations for aboveground biomass estimation by size class for Pinus brutia Ten. trees growing in North and South Aegean Islands, Greece. Eur J For Res. 130: 145-160.

\section{Sažetak}

Cilj istraživanja bio je razvoj alometrijskih jednadžbi radi procjene nadzemnih sastavnica biomase stabala kalabrijskog bora (Pinus brutia Ten.) u mediteranskom području Turske. Uporabom regresijske analize, dobivene su različite alometrijske jednadžbe za pojedine sastavnice nadzemne biomase stabla. Ukupno je 292 stabla prsnog promjera između 0,4 i 63,0 cm slučajno uzorkovano unutar prirodnog rasprostranjenja Kalabrijskog bora na mediteranskom području Turske, gdje tvori različite sastojinske strukture. Pri modeliranju i određivanju jednadžbi korišteni su prsni promjeri i visine uzorkovanih stabala kao procjenitelji. Dobivene su alometrijski jednadžbe za nadzemnu biomasu stabala Kalabrijskog bora i to zasebno za deblo, koru, grane, iglice i za ukupnu nadzemnu biomasu. Jednadžbe za deblo, koru i ukupnu biomasu objašnjavaju više od $90 \%$ ukupne varijabilnosti, dok jednadžbe za biomasu grana i iglica objašnjavaju 82 \%, odnosno 65 \% od ukupne varijabilnosti.

KLJUČNE RIJEČI: kalabrijski bor, biomasa, alometrijska jednadžba 